S sciendo International Conference KNOWLEDGE-BASED ORGANIZATION
Vol. XXVII

\title{
THE HISTORICAL ROAD MARIA THERESIA IN THE CĂLIMANI MOUNTAINS - PAST, PRESENT AND FUTURE
}

\author{
Lia-Maria CIOANCA \\ "Babeș-Bolyai" University, Cluj-Napoca, Romania \\ lia_cioanca@yahoo.com
}

\begin{abstract}
The Roman road Maria Theresia is known for its historical heritage; in the past, the troops of the Austro-Hungarian Empire housed weapons and food here. Built hundreds of years ago, the route crosses the Călimani mountains. In the elaboration of this article I applied as a research method the case study, which allowed me access to some historical and military information, namely the fact that the historical road had been designed since the time of Emperor Joseph II, but it was completed only in 1820, during the reign of Emperor Francis I of Austria. This study allowed me to collect certain data related to the way in which this road is valued and is attributed remarkable tourist values, and all this through the project undertaken by the Tăşuleasa Social Association, which aims to arrange this route as thematic path, precisely to rediscover the imperial road with the value of a historical monument, but also to highlight the natural setting of the Călimani Mountains. Throughout the investigations and the documents studied, I found that many volunteers joined this great project, to keep a road with a distant history practicable. From this case study, it appears that this road has been so well valued that it manages to attract more and more tourists, eager to know both the history of these places, but also to participate in the organized marathon or for a simple hike.
\end{abstract}

Keywords: Călimani Mountains, Via Maria Theresia, mountain area, mountain marathon, active leisure

\section{Historical-military considerations regarding the origin of the Roman road Maria Theresia}

Maria Theresa of Austria (born Erzherzogin Maria Theresia Amalia Walpurga von Österreich), also known as Maria Theresia, of the House of Habsburg, born May 13, 1717, in Vienna and died November 29, 1780 , in Vienna, was the leader of the Countries Austrian heiress between 17401780, daughter of Charles VI, RomanGerman emperor (1685-1740), wife of Emperor Francis Stephen and mother of Emperors Joseph II and Leopold II. She had the titles of Archduchess of Austria, Queen of Bohemia, Queen of Hungary, Grand Princess of Transylvania, etc. Although she was never crowned with the crown of the Holy Roman Empire, she is known as an empress due to the fact that she was married (since 1736) to Francis Stephen of Lorraine (German Franz Stephan von Lothringen), who was elected emperor. Roman-German in 1745, named Franz I Stephan. From then on, Maria Theresa held the title of Empress of the Holy Roman Empire [11].

In a century when the history of Europe was written by kings, Maria Theresa established herself as a strong and fearless leader. The Empress defended Austria during the Prussian invasion and initiated several projects aimed at improving the daily life of her people. In history, Maria Theresa is also known for being the mother 
of kings Joseph II and Leopold II, but also of the controversial queen of France, Marie Antoinette [13].

Through her reforms and avant-garde vision of the necessary changes in society, Maria Theresia was a sovereign loved and respected by her subjects, remaining in history as a symbol of how a leader can contribute to the evolution of an entire era.

\section{Via Maria Theresia - the past and present of a fairytale road}

Maria Theresia Road is a historic one, located in the Călimani Mountains, built hundreds of years ago in order to logistically support the military border troops of the Austro-Hungarian Empire with weapons and food.
This road was used quite intensely during the Austro-Hungarian rule, when it was used by both camps, strategically, to supply the border guard regiments that stretched from the Sângeorz area and the Rotunda pass near Rodna, to the historic area of Suceava Itcani- Burdujeni [2].

Nowadays, Via Maria Theresia connects the counties of Suceava and Bistrița-Năsăud. On this route you can admire the Călimani Mountains, and they, in turn, are witnesses of our history; the Dacians offered offerings for the dead, the flocks of sheep grazed the meadows, and the outlaws hid from enemies [4].

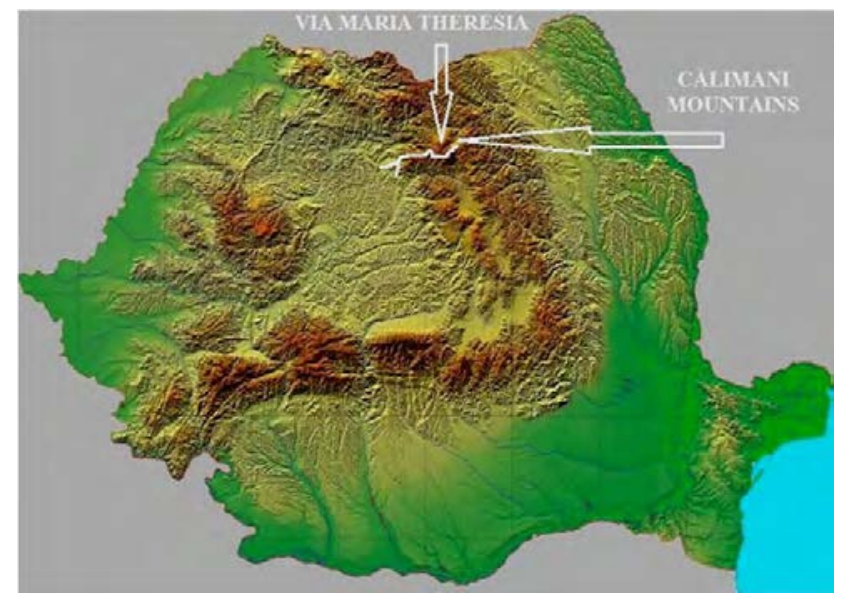

Figure 1: Geographic localization of the Via Maria Theresia Marathon route in the Călimani Mountains[5]

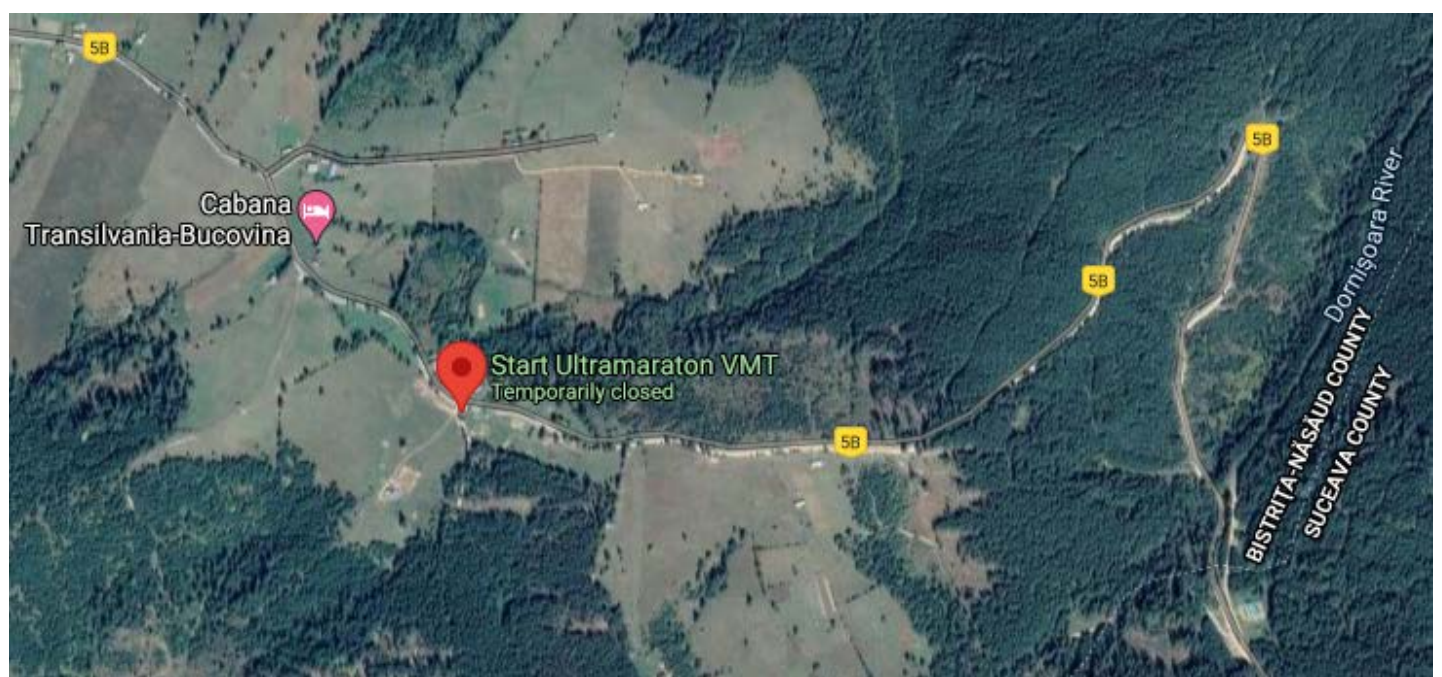

Figure 2: Google Earth location of the Roman Road Maria Theresia (processed using Google Maps) 
This road was once used to supply the front and it is said that the carriage was used on it. Today, the road is not as wide, but it is ideal for sports competitions, its positioning on the level curves of the most important peaks of the Călimanilor ridge giving the route a medium difficulty [1].

The area of the Tihuţa Pass represented the end of the western civilization or the meeting place of the western civilization with the eastern one and a crossing point between Transylvania and Bucovina. On the current route of the tourist trail in the Călimani Mountains there was an imperial road, built hundreds of years ago, in order to provide the military-border troops of the Austro-Hungarian Empire with weapons and food [3]. The historic road had been planned since the time of Emperor Joseph II, but was completed only in 1820, during the reign of Emperor Francis I of Austria.

To rediscover the imperial road as a historical monument, but also to highlight the natural setting of the Călimani Mountains, Tășuleasa Social Association, the most active and important organization in Bistrița-Năsăud County in the field of Environmental Protection and Social Involvement and Responsibility, set out to arrange this route as a thematic trail. Over 250 volunteers worked in 2014 on this route. Some parts of the old road were destroyed and others were covered. The route had to be cleaned, repaired, arranged and marked. Specially arranged resting places, signalized hydration points and information panels were installed [8].

The "Via Maria Theresia" project has several objectives. The first and most important refers to raising awareness of the importance of nature, forests and national parks, but also the practice of outdoor sports. The second objective refers to the promotion and enhancement of a road - a historical monument - thus contributing to the education of young people. In the alternative, the promotion of the Călimani National Park and the development of mountain tourism have as objective the decrease of forest crimes, due to the presence in the field of a large number of tourists, hikers and athletes. The project partner, Raiffeisen Bank, also creates the chance for 200 children to participate in the specific programs of the Tăşuleasa Social association in the Pedagogical Forest [12]. After this collective effort, in 2014 the first edition of the Via Maria Theresia Marathon mountain competition took place, a competition that takes place annually. Since the second edition, the event has already had a positive impact on the local economy. Even outside the competition period, the route benefits the community, being a permanent path. Until recently, this part of the Călimani Mountains was quite poorly marked, so too few tourists dared on the mountain trails.

Thus, Via Maria Theresia demonstrates that there is a viable alternative to current economic activities in mountain areas. Unlike logging, sustainable tourism can provide a long-term alternative for mountain villagers. Excessive grazing and illegal logging affect the environment, woodworking machines destroy mountain trails and riverbeds, and all this drives away tourists. But it is not enough to say these things to the local community, but it takes a proactive spirit, and Via Maria Theresia enjoys this advantage [12].

The benefits of the Via Maria Theresia project are not only reflected in the local community. A thematic trail is both an encouragement to practice sports and outdoor movement, and an informal way of education that emphasizes interpretation, communication and information in an interactive way. The presence of athletes and hikers in these places makes them more sensitive to environmental issues and more civically active [9].

In this sense, the Tăşuleasa Social Association organizes in the Călimani Mountains the "Via Maria Theresia" Marathon, which marks the inauguration of the thematic path of the same name. A large part of the work submitted within this 
project focused on the redevelopment of a 42-kilometer segment of the historic road of the Romanian border guards from the time of Maria Theresia, in the Călimani Mountains. The redevelopment work involved the placement of 440 wooden marking signs, marked with over 4.000 reflective plates, the pruning of vegetation that had blocked the path for tens of kilometers, the removal of stones that could have endangered the safety of tourists or athletes, the placement of rustic furniture in resting places, the installation of information panels with historical content, but also with rules for visiting a protected area [6]. All these works were carried out through voluntary work, with over 250 volunteers participating in the rehabilitation works, among which it is worth mentioning Don Lothrop, American investor and Mircea Miclea, former Minister of Education, who participated in all stages of the project, for 10 days, but also volunteers from over 12 other countries [14].

\section{The destiny of a historical road with perspectives for the development of mountain tourism}

In order to rediscover the imperial road with the value of a historical monument, but also to highlight the natural setting of the Călimani Mountains, the Tăşuleasa Social Association set out to arrange this route as a thematic path.

Following these rehabilitation works, which we discussed above, you can walk the longest themed path in the country, maintained and signposted, which will also function as a permanent marathon route, open to all those who want to train, to enjoy nature or rediscover the lost history of these places [7]. In addition to the aims of promoting sport and movement and environmental and culturalhistorical education, the project specifically aims to provide viable alternatives for local communities - so that deforestation is no longer the only source of income and to be replaced with the development of a sustainable form of mountain tourism, which promotes the beauty of the Călimani National Park and the specifics of the area [10].

The Via Maria Theresia Marathon, held in the Călimani Mountains on a historic route, arranged in the eighteenth century under the reign of Empress Maria Theresia and her son, Emperor Joseph II, is a sports competition that includes three events: half marathon ( $21.0975 \mathrm{~km}$ ), marathon (42.195 $\mathrm{km})$ and mountain biking (42.195 km). Also, on the day of the event, Tășuleasa Social organizes a hiking program, on several segments of the route, for all those who want to know the Călimani mountains, but are not ready to compete. The estimated total attendance amounts to 500-600 participants [12].

The route is more than $42 \mathrm{~km}$ long, being ideal if you want to train for the marathon, you are passionate about mountain biking or you want to take a slow walk.

Information panels, hydration points and rest areas make Via Maria Theresia an accessible route even without a guide.

The ultramarathon, marathon, mountain bike and half marathon events have as a starting point the Former Sulfur Mining Exploitation in Suceava County. The finish of the first three tests is in Piatra Fântânele, Bistriţa-Năsăud County. The half marathon route has a different finish point. Transport between Finish and Start, including bicycles is provided by the organizers.

The mountain bike route is very difficult and is recommended for cyclists with experience on technical routes [15].

Following the study, we can draw several conclusions. First of all, it turns out that Via Maria Theresia was a link between several cultures hundreds of years ago and today it shares the same purpose of intercultural link - which is why the site www.via-mariatheresia.ro was released in four languages: Romanian, Hungarian, German and English. The first three are the languages spoken in the area during the Empress's time, and English was chosen because of its wide spread, and we hope that, in this way, 
the project can be known by as many lovers of beauty, history and sports.

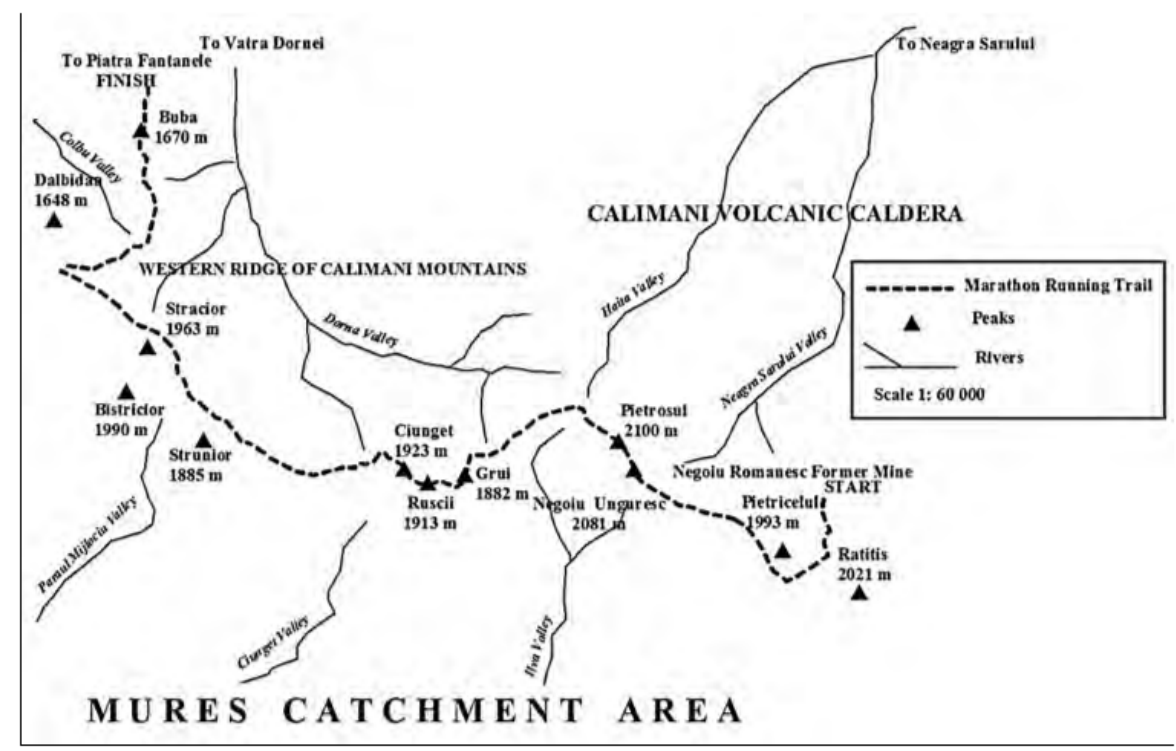

Figure 3: The route of Via Maria Theresia Marathon [5]

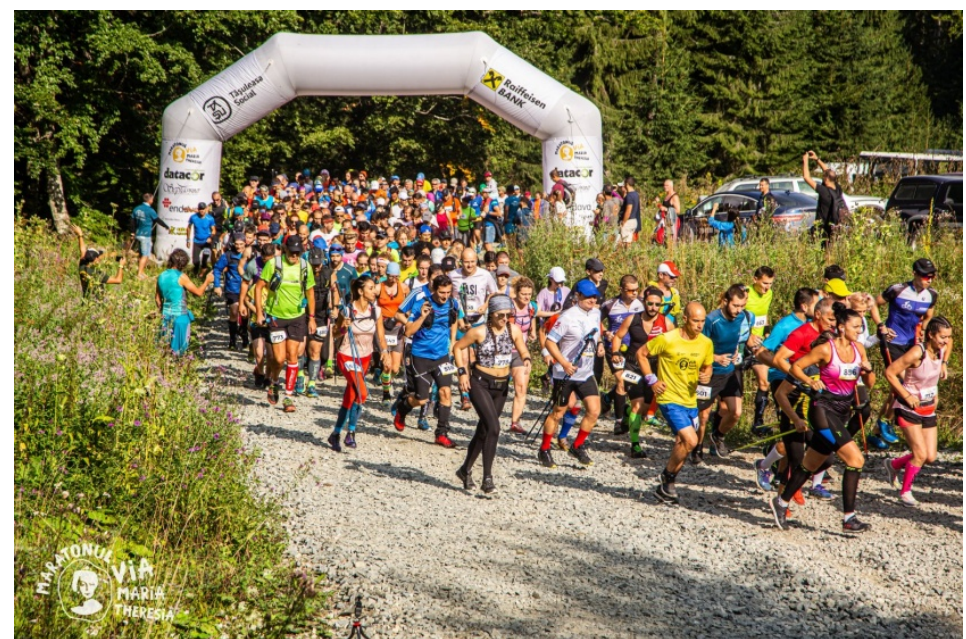

Figure 4: The starting line of the Via Maria Theresia Marathon [16]

The Tășuleasa Social Association, the initiator of the Via Maria Theresia road project, set up, in the smallest details, its organization and logistics, operations, the number of people needed, the route was recognized. In two rows, with GPS devices, the design of markings, signboards, information boards on the history of places in four languages, and many other preliminary operations were performed. For 20 years, Tăşuleasa Social has been fighting against massive deforestation, both through afforestation actions and through educational projects, such as the Pedagogical Forest. The association's efforts to save the forests go to another level, emphasizing the encouragement of as many people as possible to practice hiking and other mountain sports, in this way, they are more often present in the forests and becoming their volunteer guards [17].

Also as a conclusion, another important aspect can be noticed, namely the fact that, brought up to date by the increasingly strong development of the Vatra Dornei 
area, this Roman road could become a spectacular, original Transcarpathian road, which would highlight the most large volcanic organism in our country.

The Via Maria Theresia project is a practical demonstration of how a story and the history of the place can serve its sustainable development. The Tășuleasa
Social Association managed to transform a former historical road from the time of the Austro-Hungarian Empire into a recreational tourist route dedicated to sports activities, which will certainly contribute to the development of mountain tourism in this very picturesque area.

\section{References List}

[1] Bâca, I., Șteff, I., Colibița-dimensiuni turistice, Bistrița, Ed. Nova Didactica, 2010, pp. 44-79.

[2] Bâca, I., Arealul turistic Piatra Fântânele-Măgura Calului, Cluj-Napoca, Ed. Argonaut, 2012, pp. 172-282.

[3] Bâca, I., Șteff, I., Poveștile Colibiței, Cluj-Napoca, Ed. Argonaut, 2014, pp. 76-144.

[4] Bâca, I., Șteff, I., Bude, R., Bistricior, Cluj-Napoca, Ed. Argonaut, 2015, pp. 45-114.

[5] Bâca, I., Ștefănescu, H., Schuster, E., The exploaitation of mountain space throught sport and leisure activities. Case studies: the Via Maria Theresia Marathon from the Călimani Mountains and the Colibița Bike Fest from the Bistrița Ardeleană Gorge and the Colibița Depression, article published in Studia UBB Educatio Artis Gymn., LX, 3., 2015, pp. 83-95.

[6] Cioanca, L. M., Tourisme durable dans la contrée de Colibița, attractions touristiques actuelles et perspectives de developpement et de reliance, article published in Discourse as a Form of Multiculturalism in Literature and Communication, Tîrgu Mureș, Arhipelag XXI Press, 2015, pp. 251-258.

[7] Ferguson, S., Shevels, K., (2011), The Mountain Marathon Book, Trailguides Limited, available on http://www.amazon.com/Mountain-Marathon-Book; Accessed at Mai, 5, 2021.

[8] ***Publicația tematică Nr. 45, AN II, 2015, realizată de Ministerul Agriculturii și Dezvoltării Rurale din România în cadrul proiectului "Înființarea și sprijinirea Rețelei Naționale de Dezvoltare Rurală".

[9] ***PNDR Măsura 7 - Servicii de bază și reînnoirea satelor în zonele rurale 2014-2020.

[10] https://www.tasuleasasocial.ro/proiect/maraton-vmt-prima-editie/; accessed at Mai, 4, 2021.

[11] https://wikipedia.org; accessed at Mai, 4, 2021.

[12] https://bistritanews.ro/; accessed at Mai, 4, 2021.

[13] https://publimix.ro/blog/caleidoscop/1740-Maria-Theresa-devine-imparateasa; accessed at Mai, 4, 2021.

[14] http://via-maria-theresia.ro/; accessed at Mai, 4, 2021.

[15] https://www.romaniapozitiva.ro/moldova-bucovina/maratonul-via-maria-theresia-2015cinci-provocari-pe-un-drum-de-poveste/\#prettyPhoto; accessed at Mai, 5, 2021.

[16] https://www.facebook.com/MaratonulVmt/photos/; accessed at Mai, 5, 2021.

[17] https://branzas.ro/viata-pentru-via-drumul-maria-theresia/; accessed at Mai, 5, 2021. 